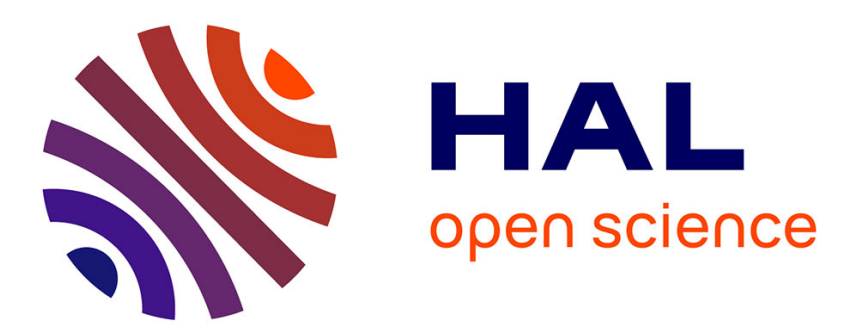

\title{
Temporal and spatial variations of the concentration of the short-lived decay products of radon in the lower atmosphere
}

\author{
J. Servant
}

\section{- To cite this version:}

J. Servant. Temporal and spatial variations of the concentration of the short-lived decay products of radon in the lower atmosphere. Tellus A, 1966, 18 (2-3), pp.663 - 671. 10.3402/tellusa.v18i2-3.9201 . hal-03402025

\section{HAL Id: hal-03402025 \\ https://hal.science/hal-03402025}

Submitted on 25 Oct 2021

HAL is a multi-disciplinary open access archive for the deposit and dissemination of scientific research documents, whether they are published or not. The documents may come from teaching and research institutions in France or abroad, or from public or private research centers.
L'archive ouverte pluridisciplinaire HAL, est destinée au dépôt et à la diffusion de documents scientifiques de niveau recherche, publiés ou non, émanant des établissements d'enseignement et de recherche français ou étrangers, des laboratoires publics ou privés. 


\section{Tellus}

\section{Temporal and spatial variations of the concentration of the short-lived decay products of radon in the lower atmosphere}

\section{J. Servant}

To cite this article: J. Servant (1966) Temporal and spatial variations of the concentration of the short-lived decay products of radon in the lower atmosphere, Tellus, 18:2-3, 663-671, DOI: 10.3402/tellusa.v18i2-3.9201

To link to this article: https://doi.org/10.3402/tellusa.v18i2-3.9201

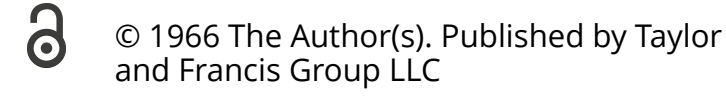
and Francis Group LLC

\section{曲 Published online: 15 Dec 2016.}

Submit your article to this journal $๘$

Џll Article views: 69

Q View related articles $₫$ 


\title{
Temporal and spatial variations of the concentration of the short-lived decay products of radon in the lower atmosphere
}

\author{
By J. SERVANT, Centre National de la Recherche Scientifique Gif-sur-Yvette (S.- \& -O.), France
}

(Manuscript received October 25, 1965)

\begin{abstract}
The study of natural radioactivity in the lower atmosphere will provide information on turbulent diffusion and transport of air masses in the lower atmosphere. We have, therefore, undertaken a two-part research program.

Firstly, we have made a study of natural radioactivity of the atmosphere above a plateau and, secondly, we have taken measurements at different latitudes and longitudes over the continents and the oceans, to obtain the general distribution of the radioactivity in the lower atmosphere.

We have found that the radioactivity of the air is much more importent over the plateau than over the oceans (100 and $6 \times 10^{-12} \mathrm{Ci} \mathrm{m}^{-3}$, respectively) and more important over the oceans in the Northern Hemisphere than in the Southern Hemisphere (6 and $1.5 \times 10^{-12} \mathrm{Ci} \mathrm{m}^{-3}$, respectively). From these results, we can suppose that it will be possible, with the aid of natural radioactivity, to identify air masses and to follow the vertical and horizontal diffusions in a given mass of air.
\end{abstract}

Some decades ago, the variations in the composition of the atmosphere were studied only by meteorologists and physicists. Today, this problem has become popular. Everyone asks about the substances that he breathes and their concentrations. To give an answer to this last point, we must study in particular the air movements in the lower atmosphere. Many workers have shown that radon is a convenient tracer for the study of movements of air masses [B1, F1, S2] and of the atmospheric stability [A1, F1, I1, J1, M1, S1, S2, T1, T2, W2]. Some of them have investigated the radioactive source-i.e. the flux of radon and its variations with the geological characteristics of the soil $[P 1, S 2, S 3, W 1]$; others, the radioactivity of the air with regard to the stability of the atmosphere; but few have shown the influence of different geographical conditions, and hence we have not a precise idea of the importance of these factors in determining the radioactivity of the air at a given site.

In this paper, we shall present the information that we have obtained with radon, continuously given off by the soil, (I) above a plateau,
(II) above a hilly site [S1], and (III) above the oceans. The geographical, geological and dynamical conditions are very different in these three sites and allow us to appreciate how these factors influence the variations of the radioactivity of the air.

\section{Study of the radioactivity of the atmos- phere above a plateau}

The site chosen is the plateau of Saclay. It is located in the boundary of the Parisian region and it spreads over several dozens of kilometers of a sedimentary soil. This site is particularly favourable for the study of the influence of different dynamical conditions on the radioactivity of the air as it represents a flat horizontal area with a uniform flux of radon throughout the year. The air analysis was made between 0 and 100 meters from a meteorological tower and radioactivity measured was that due to short lived daughter products of radon. The radioactive aerosols of the air were retained on a filter paper and the $\alpha$ activity measured instantaneously with a scintillation counter [S2].

Tellus XVIII (1966), 2 


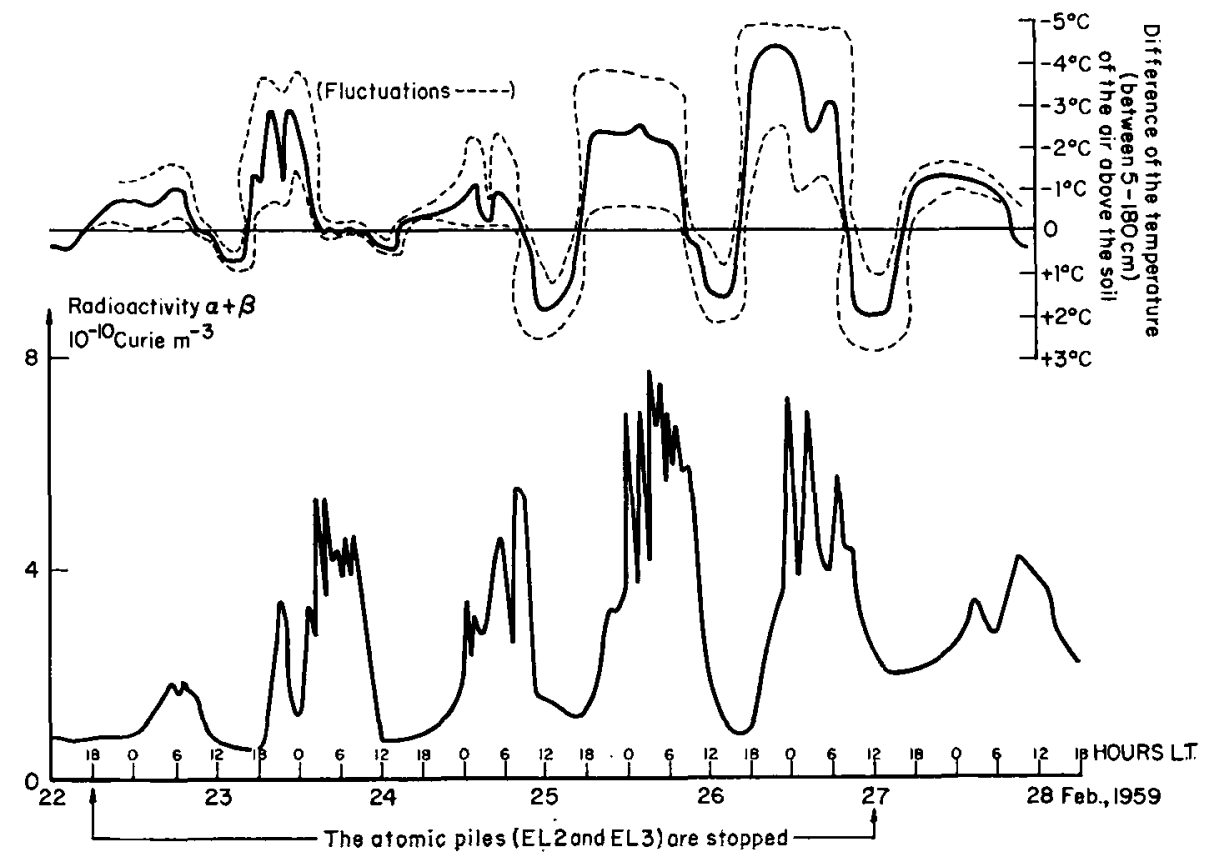

FIa. 1. Variations of the natural radioactivity, and of the difference of temperature of the air above a plateau.

\section{General observations}

In general, we have observed a succession of weak and strong concentrations of the active deposit over 24 hour periods, which is in connection with stability variations of the atmosphere due to the solar radiation, and the nocturnal radiation of the earth surface. The very high radioactivity was observed during the night when an inversion of the air temperature was detectable near the soil.

Near the soil, a typical example is given in the figure 1 . The inversion of the air temperature generally occurred only during the night. If this inversion persisted during the day, the radioactivity of the air remained high, as illustrated in figure 2 (7th, 8th and 9th February, 1960). A condition which must also hold is a wind of moderate velocity near the soil (horizontal speed less than $0.5 \mathrm{~ms}^{-1}$ ); in the region considered, the wind was blowing from N.-NE.

From 0 to 100 meters, the following recordings have been obtained (figure 3): during nights with a greater atmospheric stability, the radon emitted from the soil accumulates in a layer to the height of 30 meters (9th, 10th, 11th
September, 1961). After sunrise at $06.00 \mathrm{hr}$, the vertical transport of radon increases, whereas near the soil the atmospheric radioactivity begins to decrease and this decrease continues throughout the day. At $09.00 \mathrm{hr}$, an increase of the air radioactivity can be observed at 100 meters; this is due to the passage of the air which had stagnated near the soil during the night (the ascending speed is equal to $1 \mathrm{~cm} \mathrm{~s}^{-1}$ ). It has to be noticed that the tendency to atmospheric stability is obtained by Richardson's number as well as by the quantity of radon which accumulates in the lower atmosphere.

\section{Particular observations}

Usually, changes in natural radioactivity were slow and continual, but, sometimes during the night, rapid variations were observed (figure 4). For example, during the night of the 2nd to the 3rd October, 1961, considerable variations were recorded in radioactivity near the soil at $23.00 \mathrm{hr}, 03.00 \mathrm{hr}$ and $05.00 \mathrm{hr}$. The observation of the quantity of the active deposit in the different columns of air allows us to affirm that the column which passes between $06.00 \mathrm{hr}$ and $08.00 \mathrm{hr}$ has been submitted to certain 

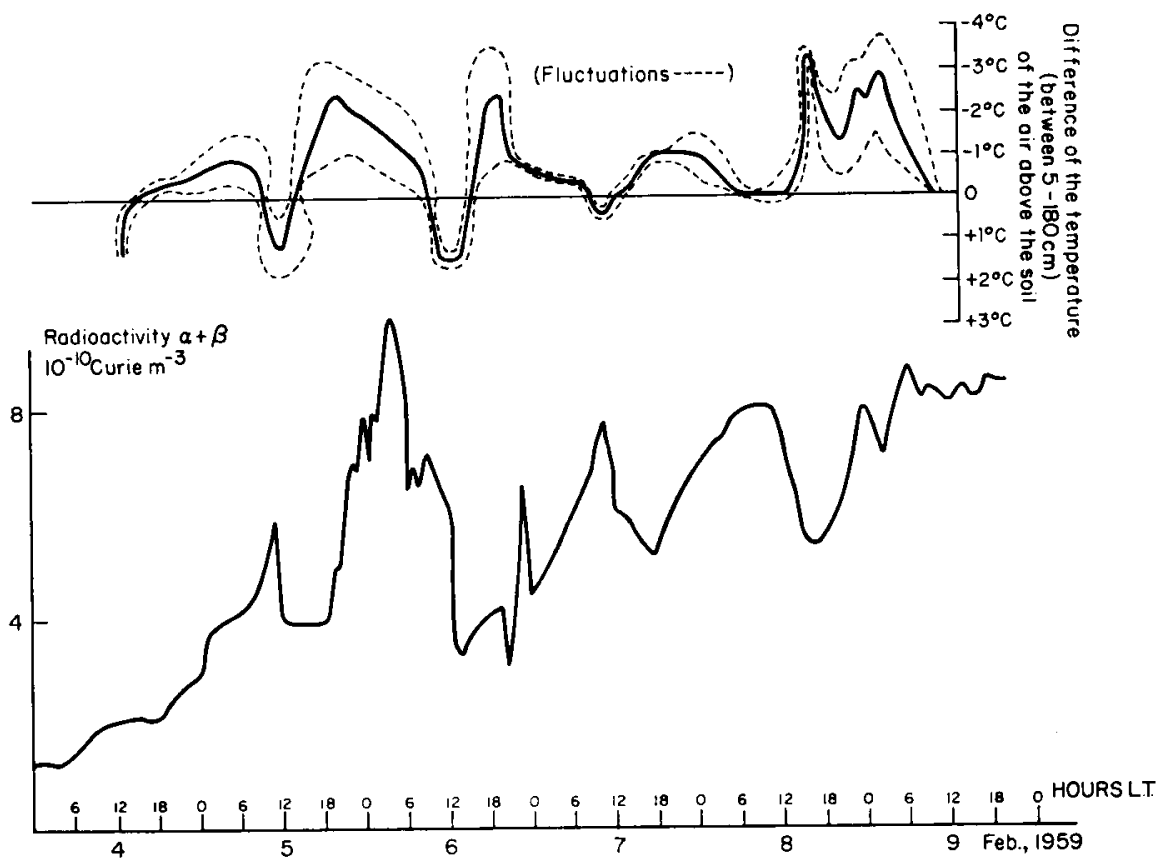

Fig. 2. Increase of the natural radioactivity of the air with an inversion of the air temperature above a plateau.

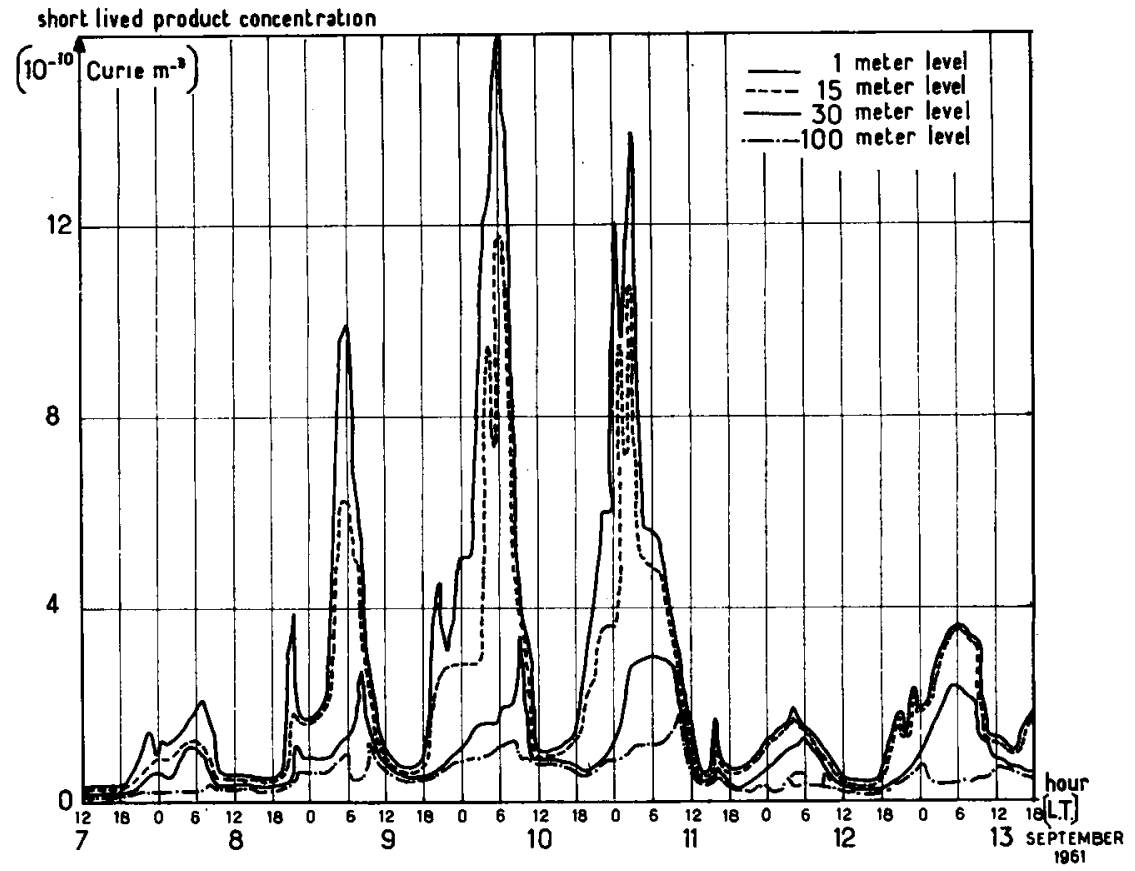

FIG. 3. Natural radioactivity of the air above a plateau (0-100 meters).

Tellus XVIII (1966), 2 


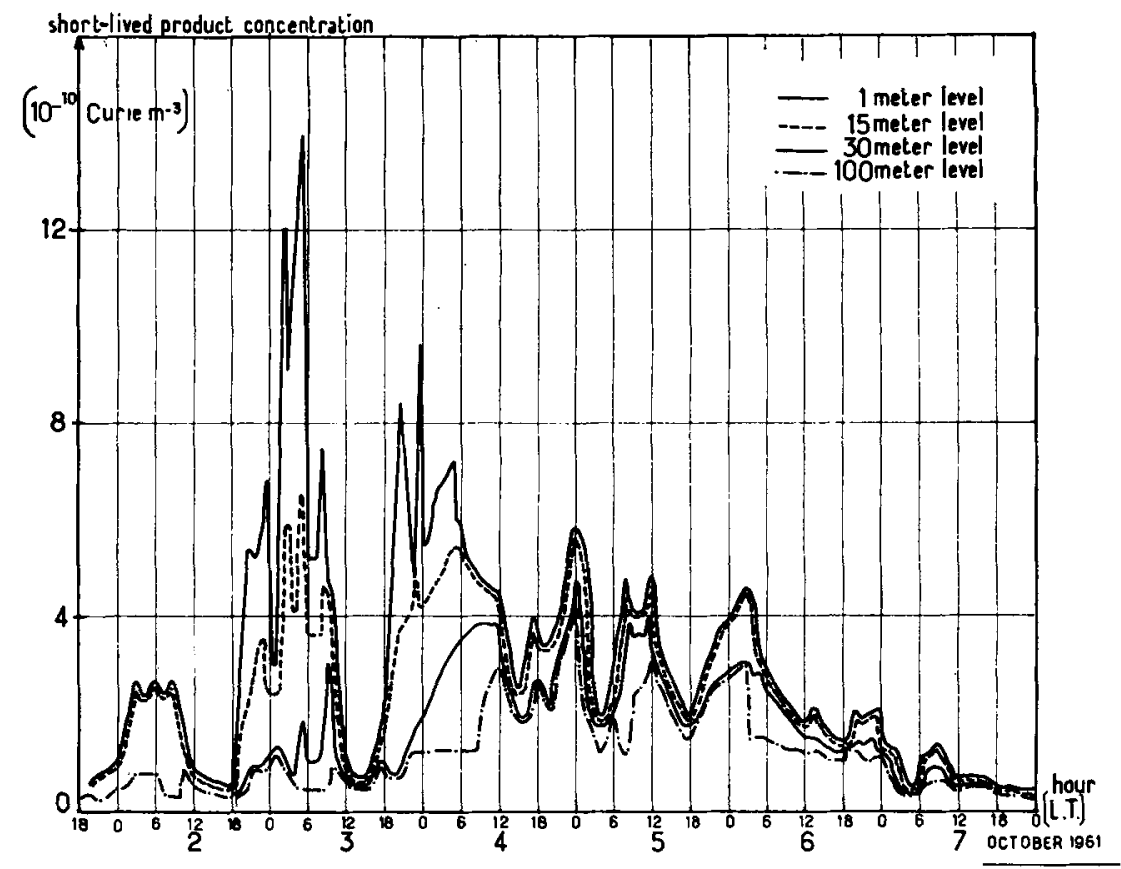

FIa. 4. Natural radioactivity of the air above a plateau (great variations during the nights).

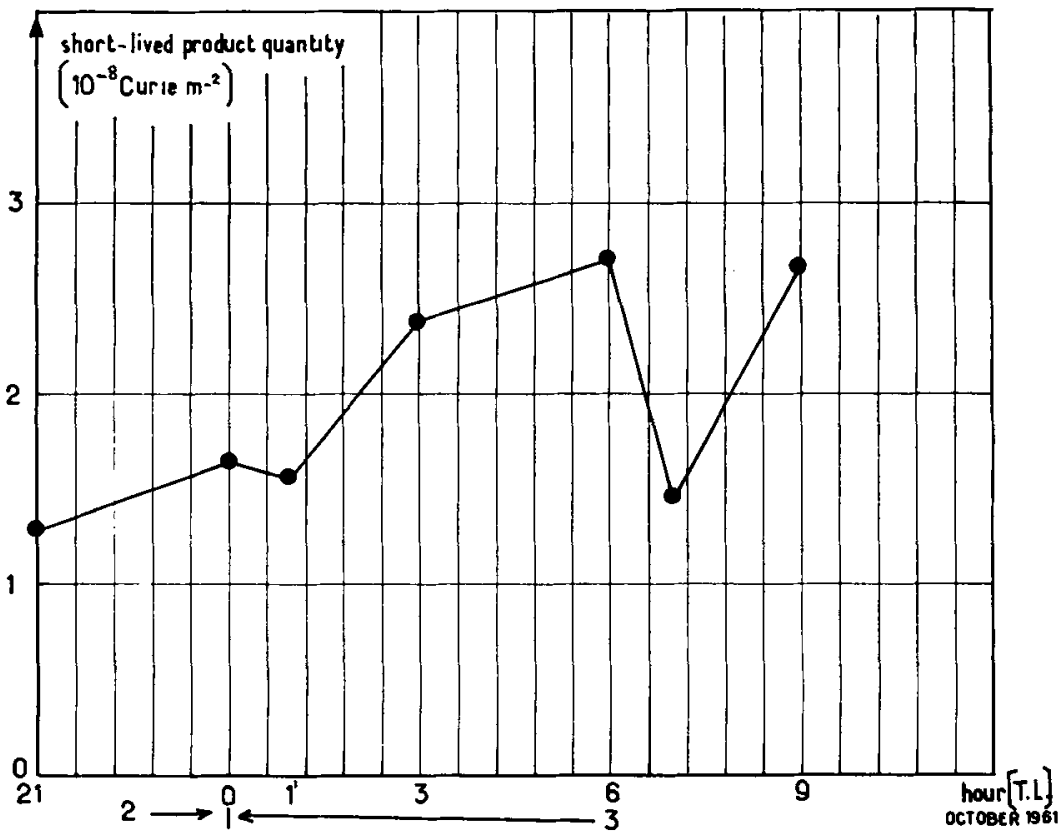

Fia. 5. Short-lived product quantity in the air columns. 


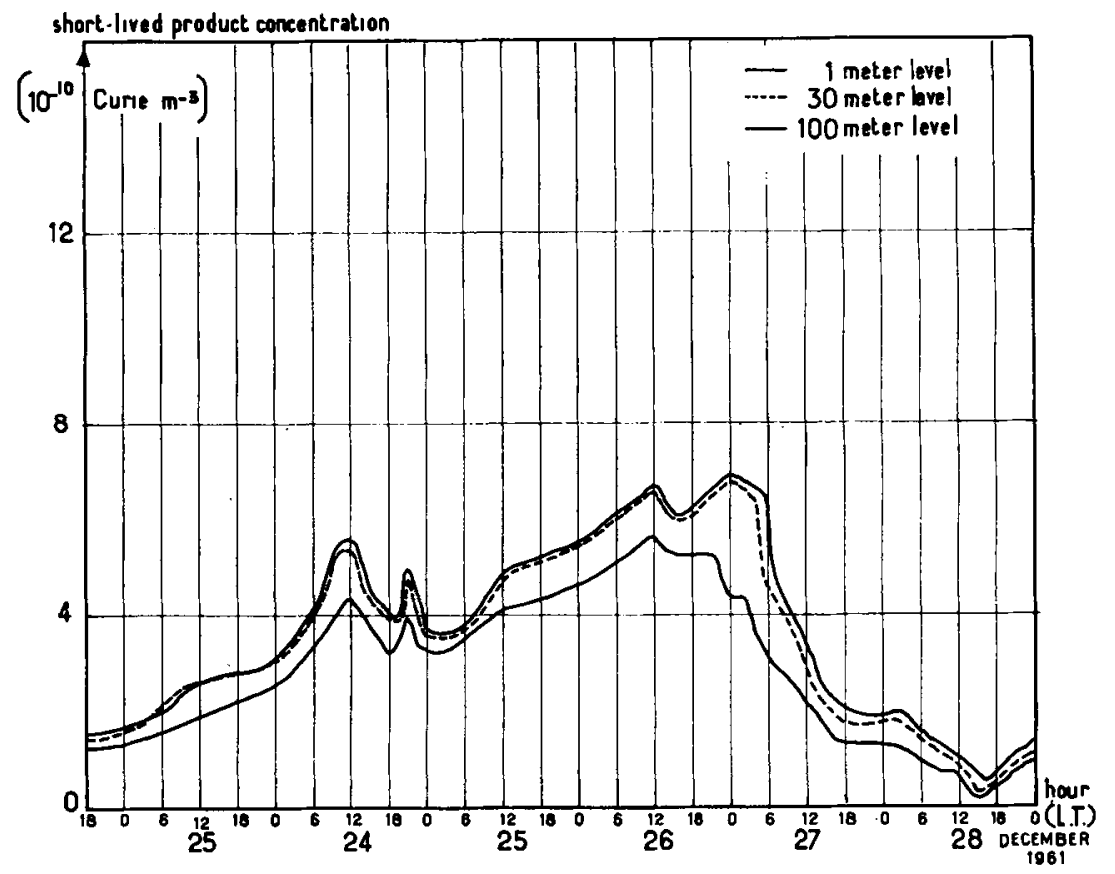

Fra. 6. Accumulation of the short-lived products of radon in the lower atmosphere.

conditions of stability different from the other columns (it has the lowest radioactivity (figure 5) and exhibits no increase in its radioactivity at 100 meters of altitude, moreover the sharp diminution of the activity at 30 meters is not usual at sunrise).

Another example of particular conditions is given in figure 6. During certain other days, the radioactivity continually increased near the soil and it was nearly constant throughout the column (0 at 100 meters).

\section{Conclusions}

1. The active deposit and radon can be used to study the stability of the atmosphere.

2. An air mass characterized by a particular temperature and relative humidity, cannot be recognized by its radioactivity when it passes on at air station, the night being sufficient for the loss of its identity.

\section{Flux of radon at a given site}

From the observed quentity of active deposit accumulated in the lower atmosphere during a clear sky night we can compute this flux; for example, at Saclay the following results have been obtained (number of observations in brackets):

$$
\begin{array}{ll}
1.55,10^{4} \text { at. } \mathrm{m}^{-2} \mathrm{~s}^{-1} & \text { July } 1961(9) \\
1.31,10^{4} \text { at. } \mathrm{m}^{-2} \mathrm{~s}^{-1} & \text { Sept. } 1961(5) \\
1.00,10^{4} \text { at. } \mathrm{m}^{-2} \mathrm{~s}^{-1} & \text { Oct. } 1961(3)
\end{array}
$$

In 1958, the values obtained with iron-bells (area $=1 \mathrm{~m}^{2}$, capacity $=100$ liters) $[\mathrm{S} 2]$ were $\mathbf{0 . 6}$ to 0.7 time lower than those given by the analysis of the atmosphere. Our result is comparable with the universal mean computed by H. Israel which is equal to $7.410^{2}$ at. $\mathrm{m}^{-2} \mathrm{~s}^{-1}$. This method has the advantage of the possibility of analysis of the degagement by a large surface (some hundred square kilometers) without any modification.

\section{Rate of renewal of air in the lower atmosphere}

The rate of air renewal has been easily determined in the lower atmosphere by meas. urements during a day following a night of high air radioactivity. For this purpose, the quantity of radon has been measured at the beginning and at the end of this period and the rate of 
TABLE 1. Rate of air renewal in the lower atmos. phere.

\begin{tabular}{lllll}
\hline $\begin{array}{c}\text { Interval } \\
\text { of time (hr)... }\end{array}$ & $6-9$ & $9-12$ & $12-15$ & $15-18$ \\
\hline Mean & 0.42 & 0.60 & 0.59 & 0.61 \\
$\begin{array}{l}\text { Range } \\
\text { (min.-max.) }\end{array}$ & $0.18-$ & $0.38-$ & $0.29-$ & $0.50-$ \\
\hline
\end{tabular}

renewal has been computed from the following expression:

$$
\frac{Q \text { initial }+Q}{Q \text { initial }+Q \text { escaped }-Q \text { final }}
$$

The air above 100 meters is assumed to be radon free and the radon flux is taken as equal to that of the previous night.

The calculations for the sunny days of July 1961 are given in Table 1. On an average, the rate of renewal is low from $06.00 \mathrm{hr}$ to $09.00 \mathrm{hr}$, then, it becomes rapid and nearly constant. However, considerable variations appear within a given period, and this fact is evident from the maximum and minimum values. From $06.00 \mathrm{hr}$ to $18.00 \mathrm{hr}, 96 \mathrm{per}$ cent of the air of the lower atmosphere is renewed by the air coming from layers higher than 100 meters.

\section{Stability of various layers of the lower atmos. phere}

The quantity of radon which stagnates in the lower atmosphere can be used to determine the stability of the air in this layer. During clear sky nights, 9th, 10th, 11th September, 1961 when the stability was high, the quantity $\mathrm{Ra} \mathrm{A}+\mathrm{Ra} \mathrm{B}+\mathrm{Ra} \mathrm{C}+\mathrm{Ra} \mathrm{C}^{\prime}+\mathrm{Ra} \mathrm{C}^{\prime \prime}$ was five times that of cloudy nights (e.g. September 8th, 1961) and 18 times that of days with high turbulence (e.g. September 7th, 1961).

In the same manner, it is possible to give more details concerning the stability of various layers: during a period of stability, 75 per cent of the radon content of the lower atmosphere is accumulated in a layer at a height lower than 30 meters, whereas during a period of strong turbulence this ratio is only 30 per cent.

\section{Measurement of the coefficient of vertical tur- bulent diffusion}

Supposing that at a given point of the plateau, the degagement of radon of the soil occurs at a constant rate and that the turbulent diffusion coefficient does not change with the altitude, we can calculate a mean coefficient. For the period of September, from the 7th to the 13th, 1961, the following results were obtained (see Table 2):

The coefficient varies from $10^{2}$ to $10^{6} \mathrm{~cm}^{2} \mathrm{~s}^{-1}$. Lower values are observed between $21.00 \mathrm{hr}$ and $09.00 \mathrm{hr}$ (between $10^{2} \mathrm{~cm}^{2} \mathrm{~s}^{-1}$ and $2.10^{4}$ $\mathrm{cm}^{2} \mathrm{~s}^{-1}$ ), and higher values between $09.00 \mathrm{hr}$ and $21.00 \mathrm{hr}$ (between $7.10^{2} \mathrm{~cm}^{2} \mathrm{~s}^{-1}$ and $10^{6} \mathrm{~cm}^{2}$ $\mathrm{s}^{-1}$ ). The values lower than $10^{3} \mathrm{~cm}^{2} \mathrm{~s}^{-1}$ are attained only during the nights when the stability of the atmosphere is remarkable (9th, 10th, 11th September, 1961).

\section{Study of the radioactivity of the atmos- phere at a hilly site}

This site is located in the Morvan region. The observations have been made near the soil

TABLE 2. Mean coefficient of vertical turbulent diffusion in the lower atmosphere.

\begin{tabular}{crrrrrrrr}
\hline $\begin{array}{c}\text { Time (L.T.), } \\
\text { hr... }\end{array}$ & $18-21$ & $21-0$ & $0-3$ & $3-6$ & $6-9$ & $9-12$ & $12-15$ & $15-18$ \\
\hline $\begin{array}{c}\text { Date } \\
\text { (Sept. 1961) }\end{array}$ & & & & & & & & \\
7 & & & & & & & & \\
8 & $4 \cdot 10^{4}$ & $10^{4}$ & $10^{4}$ & $4 \cdot 10^{3}$ & $6 \cdot 10^{3}$ & $10^{3}$ & $4 \cdot 10^{5}$ & $4 \cdot 10^{5}$ \\
9 & $8 \cdot 10^{2}$ & $2 \cdot 10^{4}$ & $2 \cdot 10^{3}$ & $2 \cdot 10^{2}$ & $10^{4}$ & $6 \cdot 10^{4}$ & $2 \cdot 10^{5}$ & $9 \cdot 10^{4}$ \\
10 & $7 \cdot 10^{2}$ & $10^{3}$ & $10^{3}$ & $10^{2}$ & $7 \cdot 10^{3}$ & $10^{5}$ & $10^{5}$ & $2 \cdot 10^{4}$ \\
11 & $2 \cdot 10^{3}$ & $10^{3}$ & $3 \cdot 10^{2}$ & $3 \cdot 10^{3}$ & $5 \cdot 10^{3}$ & $3 \cdot 10^{4}$ & $10^{8}$ & $10^{5}$ \\
12 & $9 \cdot 10^{4}$ & $10^{4}$ & $8 \cdot 10^{3}$ & $2 \cdot 10^{4}$ & $2 \cdot 10^{4}$ & $10^{5}$ & $9 \cdot 10^{4}$ & $9 \cdot 10^{4}$ \\
13 & $8 \cdot 10^{3}$ & $4 \cdot 10^{3}$ & $4 \cdot 10^{3}$ & $3 \cdot 10^{3}$ & $3 \cdot 10^{3}$ & $4 \cdot 10^{4}$ & $5 \cdot 10^{4}$ & $7 \cdot 10^{3}$ \\
\hline
\end{tabular}




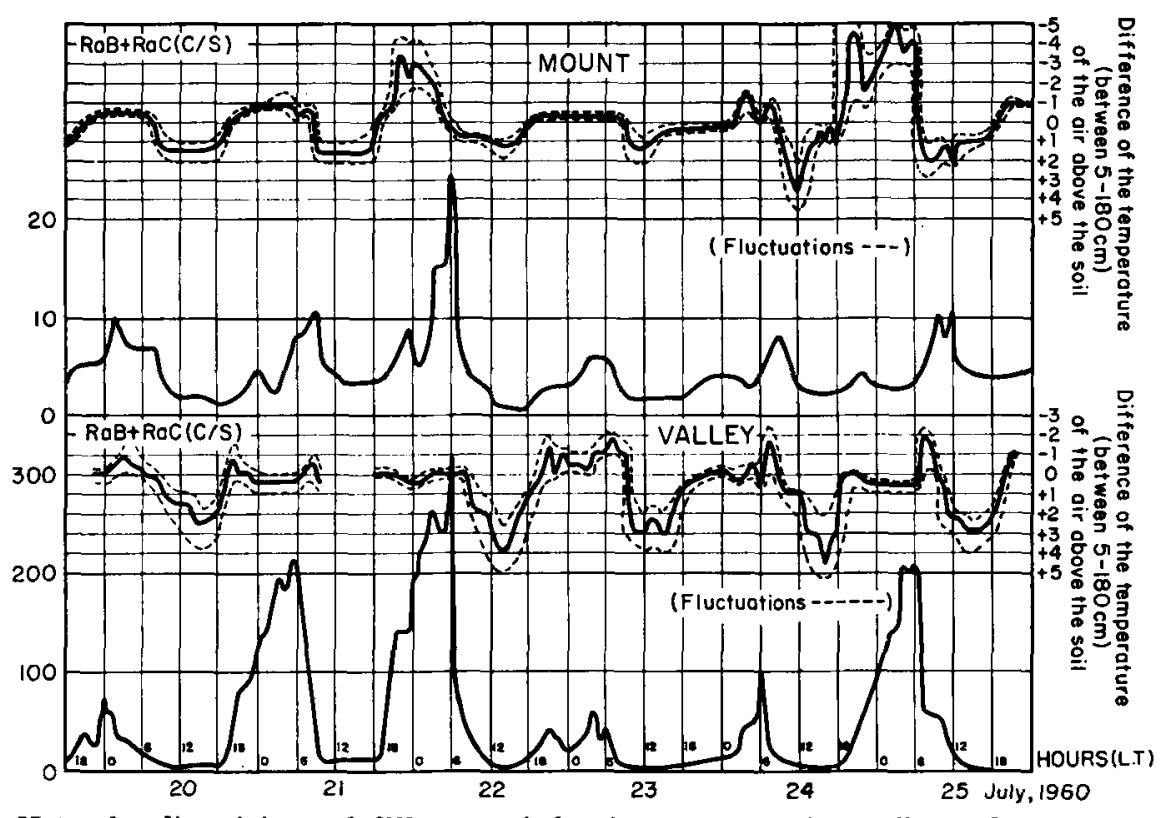

FIa. 7. Natural radioactivity and difference of the air temperature in a valley and on a mount.

in a valley and on an isolated mount. These two stations of measurements are separated by a distence of four kilometers and the difference of altitude is $\mathbf{3 2 0}$ meters. This site differs from the plateau of Saclay in its geography and its granitic soil. We have studied the influence of these variations in geological and geographical conditions and an example of the observations recorded is given in figure 7 .

We have observed that the radioactivity of the air in the valley is proportional to the radio. activity of the granitic rocks only at night, and then is ten or twenty times higher than over the mount. Hence, near the soil of the valley, the radioactivity is fifteen times higher than at Saclay, i.e. $7.510^{-8} \mathrm{Ci} \mathrm{m}-8$ or five times the permissible dose for the population $\left(1.5 \times 10^{-8}\right.$ Ci $\left.\mathrm{m}^{-3}\right)$. During the day, the radioactivity has usually the same value in the valley, on the mount and at Saclay. We have also observed downslope breezes during the nights (21st, 22nd, 24th, 25th July, 1960) with a speed of $0.2 \mathrm{~ms}^{-1}$. After the sunrise, the upslope breeze is marked by the increase of the radioactivity on the mount at $09.00 \mathrm{hr}$ (21st, 26th, 25th July, 1960).

III. Study of the radioactivity of the air above the oceans (at sea level)

The results obtained over several years are given in the Table 3 . The radioactivity of the
TABLE 3. The activity of the air due to the shortlived daughter products of radon collected on filter papers.

\begin{tabular}{|c|c|c|}
\hline Place & $\begin{array}{c}\text { Mean } \\
\text { annual } \\
\left(10^{-12} \mathrm{Ci} \mathrm{m}^{-8}\right)\end{array}$ & $\begin{array}{c}\operatorname{Min} .-M 8 x \\
\left(10^{-12} \mathrm{Ci} \mathrm{m}^{-3}\right)\end{array}$ \\
\hline Mediterranean Sea ${ }^{\mathfrak{a}}$ & 100 & $30-200$ \\
\hline Red Sea + Aden gulf ${ }^{b}$ & 50 & $13-90$ \\
\hline Indian Ocean ${ }^{c}$ & 2 & $0-9$ \\
\hline N. Atlantic Ocean ${ }^{d}$ & 6 & $0-280$ \\
\hline Caribbean Sea ${ }^{e}$ & 7 & $0.7-26$ \\
\hline S. Pacific Ocean ${ }^{f}$ & 1.5 & $0.2-9.2$ \\
\hline Tasmanian Sea & 3.7 & $0.5-15.8$ \\
\hline \multicolumn{3}{|l|}{ Antarctic Ocean } \\
\hline Terre Adélie ${ }^{h}$ & 0.8 & $0-4$ \\
\hline
\end{tabular}

a 4 measures in Novernber 1964.

b 8 measures in November 1964.

c 2 years of measurement at the Kerguelen islands +22 measures between $20^{\circ} \mathrm{N}$ and $50^{\circ} \mathrm{S}$ in December 1884.

d 3 years of measurement at point $A, J, K$ ( 1959 $1962)+25$ measures between $20^{\circ} \mathrm{N}$ and $45^{\circ} \mathrm{S}$ in December 1963-1964. (Measures made by G. Lambert.)

e 8 measures in December 1963 and December 1864.

$f 2$ measures in December 1963 and December 1964.

- 15 measures in December 1963 and December 1964.

$h 3$ years of measurement in Terre Adélie (19591962) and on the Ocean (1963-1964). (Messures made by $G$. Lambert and G. Polian.)

Tellus XVIII (1966), 2

$42 \dagger-662895$ 
air at the surface of the oceans is 10 to 100 times lower than that above the continent $\left(100 \times 10^{-12} \mathrm{Ci} \mathrm{m}^{-3}\right)$ and about 2 to 6 times lower in the southern hemisphere than in the northern hemisphere. This activity is due partly to the diffusion of radon in the upper layers of the low air of the atmosphere (near the shores) and to the radioactive decrease of the radon during its travel above the oceans which have a flux of nearly zero. For example, we have noted that an air mass which started from the Kerguelen Islands with an activity of $1 \times 10^{-12} \mathrm{Ci} \mathrm{m}^{-3}$ passed over Australia with an activity of $0.5 \times 10^{-12} \mathrm{Ci} \mathrm{m}^{-3}$; this decrease agrees with the time taken by the air mass to go from the first station of measurement to the second station. The fluctuations near the mean value are due to the passage of the air masses of different origins [F1] and of different initial radioactivity.

\section{Conclusion}

The concentration of radon in the air of the lower atmosphere around the earth shows very important variations. It attains its maximum, $75,000 \times 10^{-12} \mathrm{Ci} \mathrm{m}^{-3}$, above the continents and its minimum, $10^{-12} \mathrm{Ci} \mathrm{m}^{-3}$, above the oceans, differing by a factor of $7.5 \times 10^{4}$.

Above the continents, the radioactivity of the air is controlled by the local meteorological, geological and dynamical conditions and gives a picture of the rate of the accumulation or of the escape from the lower atmosphere of a substance released by the soil.

For example, above the plateau, the radioactivity of the air is in direct relation with the stability of the atmosphere; in a hilly site, placed on a geoanomalous area, the radioactivity is governed by the stability of the atmosphere by the duration of the passage of air above the anomalous region and by the geographical position (e.g. during the night, the increase of the radioactivity is high in the valley but low on the mount). In general, these results confirm the previous meteorological observations. However, they give new preoisions, above all in determining the stability of the atmosphere.

Above the oceans, there are the general meteorological conditions which determine the level of this radioactivity which becomes a witness of the history of the turbulent diffusion at a mean and a large scale.

\section{REFERENCES}

Al. Ardouin, B., Jeharno, C., Labeyrie, J., Lambert, G., Tanaevsky, $O$., and Vassy, E., 1963, Résultats des mesures de concentration dans la basse atmosphère des aérosols radioactifs artificiels. Rapport C.E.A., $\mathbf{n}^{\circ} 2261$.

BI. Becker, F., 1934, Messungen des Emanationsgehaltes der Luft in Frankfurt a.M. und am Taunus-Observatorium. Beitr. Geophys., 42, pp. 365-384.

F1. Fontan, J., 1964, Le dosage des radioéléments gazeux donnant des produits radioactifs de filiation. Son application a la mesure de la radioactivité naturelle de l'atmosphère. Thèse $\mathrm{n}^{\circ} 218$ de la Faculté des Sciences de l'Université de Toulouse.

I1. ISRAËL, G. W., 1965, Der Thorongehalt in der bodennahen Atmosphäre. Dissertation, Technischen Hochschule Aachen.

JI. JАCOBI, W., 1963, The vertical distribution of Rn-222, Rn-220 and their decay products in the atmosphere, J.G.R., 68, pp. 3799-3814.

MI. Les isotopes radioactifs dans l'atmosphère et leur utilisation en météorologie. Moscou 1965.

M2. Moses, H., Stehney, A. F., and Lucas, H. F., JR., 1960, The effect of meteorological variables upon the vertical and temporal distributions of atmospheric radon. Journal of Geoph. Res., 65, Nb 4, pp. 1223-1238.
P1. Pearson, J. E., 1965, Radon-222. A study of its emanation from soil, source strength, and use as a tracer. Research reports, Dept. of General Eng., Univ. of Illinois. WRBANA.

S1. Sснмірт, W., 1926, Zur Verteilung radioaktiver Stoffe in der freien Luft. Phys. Zeitschr., 27, pp. 371-377.

S2. Servant, J., 1964, Le radon et ses dérivés à vie courte dans la basse atmosphère. Thèse de doctorat ès Sciences, Paris. Rapport C.E.A., R.2434.

S3. Sissigina, T. T., 1962, The measurement of the exhalation of radon from the surface of certain types of rocks. Problems of Nuclear Meteorology. Ed. by I. L. Karou and S. G. MaLakhov, Moscow. AEC - tr. 6128 - TID 4500, 25th Ed., pp. 125-138.

T1. Tanaevsky, O., and VAssy, E., 1955, Variations de la radioactivité naturelle et artificielle de l'atmosphère. C.R., 241, pp. 38-40.

T2. Tanaevsky, O., and Vassy, E., Radioactivité naturelle et artificielle de l'atmosphère. Annales de Géophysique, 11, Fs. 4, pp. 486-490.

W1. Wilkening, M. H., and HaNd, J. E., 1960, Radon flux at the earth air interface. Journal of Geoph. Res., 65, No. 10, October.

W2. WILKeniNe, M. H., 1959, Daily and annual courses of natural atmospheric radioactivity. Journal of Geoph. Res., 64, pp. 521-526.

Tellus XVIII (1966), 2 
ВРЕМЕННЫЕ И ПРОСТРАНСТВЕННЫЕ ИЗМЕНЕНИЯ КОНЦЕНТРАЦИИ КОРОТКО. ЖИВУЩИХ ПРОДУКТОВ РАДИОАКТИВНОГО РАСПАДА РАДОНА В НИЖНЕЙ АТМОСФЕРЕ

Поскольку изучение естественной радиоактивности в нижней атмосфере может давать в будущем информацию о турбулентной диффузии и переносе воздушных масс, мы предприняли исследование состоящее из двух частей.

Во-первых мы изучили естественную радиоактивность атмосферы над плоскогорьем, во-вторых произвели измеренин в различных местах земного шара для получения общего распределения радиоактивности в нижней атмосфере. Мы нашли, что радиоактивность над плоскогорьем намного больше, чем над онеанами $\left(100\right.$ и $6 \times 10^{-12} \mathrm{Ci} \mathrm{M}^{-3}$ соответственно) и в северном полушарии больше, чем в южном (6 и $15 \times 10^{-12} \mathrm{Ci} \mathrm{M}^{-3}$ соответственно).

Основываясь на этих данных мы считаем возможным с помоцью естественной радио. активности индивидуализировать массы воздуха и следить за вертикальной и горизонтальнои диффузиями в них. 